\title{
EFFECT OF CEMENT ALTERNATIVES ON THE MECHANICAL PROPERTIES OF SELF-COMPACTING CONCRETE USING VARIABLE AGGREGATE TYPES*
}

\author{
Hamdy A-k Shehab, Mohamed A. Almetwally, Salah E. Abd El-mageed and Mohamed R. A. Emara+ \\ Structural Eng. Deprt., Faculty of Engineering, Zagazig University, Zagazig, Egypt
}

\begin{abstract}
Self-compacting Concrete (SCC) is a new category of High Performance Concrete with high workability and flowability but without segregation. This concrete has the advantages of being compacted easily under its own weight without the need of any external compacting energy. The current research studied the properties of SCC containing different powder types (fly ash, silica fume and metakaoline) and different aggregate types (gravel, basalt and dolomite) compared with that of SCC without any powders. A trial mixes were done to obtain the water/powder ratio and the amount of super-plasticizer to ensure the self compactability conditions. Fresh properties of SCC were tested and the results indicated that all mixes satisfied the allowable ranges for slump flow time (T50), slump flow diameter (D), and V-Funnel flow time. Also the hardened properties of SCC were tested and the results indicated that mixes containing dolomite as a coarse aggregate gives the highest values for both compressive and tensile strength. On the other hand mixes containing gravel as a coarse aggregate gave the lowest values. Also, the results indicated that incorporating powders (FA, SF, and MK) as a partial replacement of cement has a little increase in the compressive strength after 3 days than that of the control mixes at a certain percentages, and gives a marked increase in the values of the compressive strength after 28 days, but this incorporation has a little effect on tensile strength.
\end{abstract}

KEY WORDS: Self-Compacting Concrete; Aggregate; Fly ash; Silica fume; Metakaoline.

\section{EFFET DES ALTERNATIVES CIMENT SUR LES PROPRIETES MECANIQUES DES BETONS AUTO-PLAÇANTS UTILISANT LA VARIABLE TYPES GLOBALE}

\section{RÉSUMÉ}

Bétons auto-plaçant $(\mathrm{CCN})$ est une nouvelle catégorie de béton haute performance avec grande ouvrabilité et la fluidité, mais sans ségrégation. Ce béton a l'avantage d'être facilement compacté sous son propre poids sans avoir besoin d'aucune énergie extérieure compactage. La recherche actuelle étudie les propriétés de la CSC contenant différents types de poudre (cendres volantes, fumées de silice et de metakaoline) et différents types agrégats (gravier, le basalte et la dolomite) comparée à celle de la CSC sans poudres. Un mélange d'essai ont été effectués pour obtenir le rapport eau / poudre et le montant de super-plastifiant pour assurer les conditions compactage auto. Propriétés frais de SCC ont été testés et les résultats ont indiqué que tous les mélanges satisfait les plages autorisées pour le temps étalement (T50), diamètre étalement (D), et le temps d'écoulement V-Funnel. Aussi les propriétés durcie de la CSC ont été testés et les résultats indiquent que des mélanges contenant de dolomite comme un gros granulat donne les plus hautes valeurs pour la force à la fois la compression et de traction. D'autre part les mélanges contenant du gravier comme un gros granulat donné valeurs les plus basses. En outre, les résultats indiquent que l'incorporation de poudres (FA, SF, et $\mathrm{MK}$ ) comme un remplacement partiel du ciment a une faible augmentation de la résistance à la compression après 3 jours que celui de la commande mêle à un certain pourcentage, et donne une augmentation marquée de les valeurs de la résistance à la compression après 28 jours, mais cette incorporation a un peu d'effet sur la force de traction.

MOTS CLES: béton auto plaçant; granulats; cendres volantes; fumée de silice; Metakaoline.

* Received: 3/7/2011, Accepted: 7/8/2011, (Original Paper)

+ Contact Author (+20 104398273) 


\section{INTRODUCTION}

Self compacting concrete (SCC) represents one of the most significant advances in concrete technology for decades. Inadequate homogeneity of the cast concrete due to poor compaction or segregation may drastically lower the performance of mature concrete in-situ. SCC has been developed to ensure adequate compaction and facilitate placement of concrete in structures with congested reinforcement and in restricted areas. SCC was developed first in Japan in the late 1980s to be mainly used for highly congested reinforced structures in seismic regions [1]. As the durability of concrete structures became an important issue in Japan, an adequate compaction by skilled labors was required to obtain durable concrete structures. This requirement led to the development of SCC and its development was first reported in 1989 [2]. SCC can be described as a high performance material, which flows under its own weight without requiring vibrators to achieve consolidation by complete filling of formworks even when access is hindered by narrow gaps between reinforcement bars [3]. SCC can also be used in situations, where it is difficult or impossible to use mechanical compaction for fresh concrete, such as underwater concreting, cast in-situ pile foundations, machine bases and columns or walls with congested reinforcement. The high flow ability of SCC makes it possible to fill the formwork without vibration [4]. Since its inception, it has been widely used in large construction in Japan [5]. It can also be regarded as "the most revolutionary development in concrete construction for several decades". Originally developed to offset a growing shortage of skilled labor, it is now taken up with enthusiasm across European countries for both site and precast concrete work. It has proved beneficial economically [6-7]. At the beginning of the twentieth century, interest in SCC has grown in the United States, particularly within the precast concrete industry. SCC has been used in several commercial projects [8-9]. Numerous research studies have been conducted recently with the objective of developing raw material requirements, mixture proportions, material requirements and characteristics, and test methods necessary to produce and test SCC. The latest studies related to SCC focused on improved reliability and prediction of properties, production of a dense and uniform surface texture, improved durability and both high and early strength permitting faster construction and increased productivity [10-12]. With regard to its composition, SCC consists of the same components as conventionally vibrated normal concrete, which are cement, aggregates, water, additives and admixtures. However, high volume of superplasticizer for reduction of the liquid limit and for better workability, the high powder content as "lubricant" for the coarse aggregates, as well as the use of viscosity-agents to increase the viscosity of the concrete have to be taken into account[13]. Fig. 1 shows the basic principles for the production of SCC.

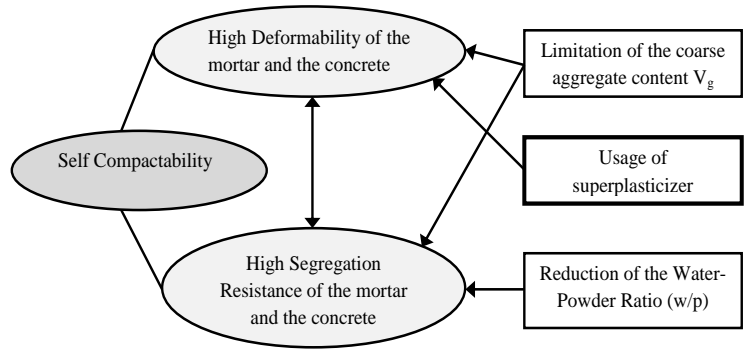

Fig. 1 Basic principles for the production of SCC

The term 'powder' used in SCC refers to a blended mix of cement and filler particles smaller than $0.125 \mathrm{~mm}$. The filler increases the paste volume required to achieve the desirable workability of SCC. The addition of filler in an appropriate quantity enhances both workability and durability without 
sacrificing early strength [14]. Materials, such as fly ash, blast furnace slag, ground glass, limestone powder, silica fume, etc, are commonly used as filler for producing SCC. Savings in labor costs might offset the increased cost related to the use of more cement and superplasticizer, but the use of limestone powder (LSP) as filler could increase the fluidity of the concrete, without any increase in the cost [15]. Fly ash is an effective mineral admixture on fresh properties of SCC mortar up to $20 \%$ as replacement ratio of cement. However 20 to $30 \%$ fly ash replacement was not enough to show positive effect on fresh properties of SCC mortar due to its low specific surface area [16].

\section{EXPERMENTAL PROGRAM}

\subsection{Variables}

The main variables in this study are:

- Powder type fly ash(FA), silica fume(SF), and metakaoline(MK)

- Proportion of powder as a partial replacement of cement content $(5 \%$, $10 \%$, and $15 \%$ ).

- Aggregate type (gravel, basalt, and dolomite)

The following parameters were kept constant in the study:

- Total amount of powder content $($ cement + powder $)=450 \mathrm{~kg} / \mathrm{m}^{3}$.

- Water/powder ratio $=0.45$.

- Super plasticizer with constant content of $1.5 \%$ by weight of powder.

The ratio of coarse aggregate to fine aggregate content by weight $=1: 1$

For basalt and dolomite aggregate size1 to size 2 to ratio $=1: 1$ by weight

The previous constant parameters were obtained from a trial mixes.

\subsection{Materials}

Ordinary Portland cement complying with the
Egyptian Standard Specifications (ESS 373/1991) was used throughout the mixes of this study. Clean siliceous sand was chosen as fine aggregates for all concrete mixes used in this experimental program. Sieve analysis was carried out. Natural Gravel, Dolomite and Basalt as coarse aggregates were used in the preparation of self compacting concrete (SCC). In order to ensure that the used aggregates are free from impurities; aggregates were washed and left to dry at room temperature. The maximum aggregate size of the used aggregates is $20 \mathrm{~mm}$. Sieve analysis for coarse and fine aggregate used was presented in Table 1. Superplasticizing admixture (Sika viscocrete-5920) was used to increase workability of all SCC mixes to obtain strong self-compacting behavior. The used super- plasticizer complies with ASTM C 494 types $\mathrm{G}$ and $\mathrm{F}$ and BS EN 934 part2:2001. The properties of Sika Viscocrete- 5920 are presented in Table 2. Clean tap drinking water was used in all mixes. Fly ash, silica fume, and metakaoline used in this study are in conformance with ASTM C-1116. The chemical and physical properties of these powders are shown in Tables 3 and 4.

Table 1: Sieve analysis and physical properties of the fine and coarse aggregates.

\begin{tabular}{|c|c|c|c|c|c|c|}
\hline \multirow{4}{*}{$\begin{array}{l}\text { Sieve } \\
\text { size } \\
(\mathrm{mm})\end{array}$} & \multicolumn{6}{|c|}{$\%$ passing } \\
\hline & \multirow{3}{*}{ Sand } & \multicolumn{5}{|c|}{ Coarse aggregate } \\
\hline & & \multirow[b]{2}{*}{ Gravel } & \multicolumn{2}{|c|}{ Basalt } & \multicolumn{2}{|c|}{ Dolomite } \\
\hline & & & $\begin{array}{c}\text { Size } \\
1\end{array}$ & $\begin{array}{c}\text { Size } \\
2\end{array}$ & $\begin{array}{c}\text { Size } \\
1\end{array}$ & $\begin{array}{c}\text { Size } \\
2\end{array}$ \\
\hline 37.5 & 100 & 100 & 100 & 100 & 100 & 100 \\
\hline 20 & 100 & 100 & 100 & 95.3 & 100 & 95.4 \\
\hline 14 & 100 & 92.7 & 94.6 & 29.4 & 93.4 & 22.5 \\
\hline 10 & 100 & 51.4 & 31 & 12.2 & 25.5 & 10.6 \\
\hline 4.67 & 93.7 & 1.3 & 4.8 & 2.2 & 4.2 & 2.1 \\
\hline 2.36 & 89.7 & - & - & - & - & - \\
\hline 1.18 & 80.8 & - & - & - & - & - \\
\hline 0.6 & 45.1 & - & - & - & - & - \\
\hline 0.3 & 14.7 & - & - & - & - & - \\
\hline 0.15 & 1.8 & - & - & - & - & - \\
\hline $\begin{array}{c}\text { Specific } \\
\text { weight }\end{array}$ & 2.6 & 2.7 & & & & \\
\hline $\begin{array}{c}\text { Bulk } \\
\text { density } \\
\left(\mathrm{t} / \mathrm{m}^{3}\right)\end{array}$ & 1.8 & 1.8 & & & & \\
\hline
\end{tabular}


EFFECT OF CEMENT ALTERNATIVES ON THE MECHANICAL PROPERTIES OF SELF-COMPACTING CONCRETE USING VARIABLE AGGREGATE TYPES

Shehab, Almetwally, El-maged and Emara

Table 2: Properties of the superplasticizer.

\begin{tabular}{|c|c|}
\hline Property & Description \\
\hline Base & $\begin{array}{c}\text { aqueous solution of } \\
\text { modified } \\
\text { polycarboxylates }\end{array}$ \\
\hline Appearance/Color & light brownish liquid \\
\hline Specific gravity & $1.09 . \pm 0.01 \mathrm{~kg} /$ lit \\
\hline Solid content & $36 \%$ \\
\hline
\end{tabular}

Table 3: Chemical properties of powders

\begin{tabular}{|c|c|c|c|}
\hline \multirow{2}{*}{ Constituents } & \multicolumn{3}{|c|}{ Percentage by weight } \\
\cline { 2 - 4 } & FA & SF & MK \\
\hline Loss on ignition & 4.17 & 1.84 & 0.98 \\
\hline Silica $\left(\mathrm{SiO}_{2}\right)$ & 58.5 & 91 & 52.6 \\
\hline Iron Oxide $\left(\mathrm{Fe}_{2} \mathrm{O}_{3}\right)$ & 3.44 & 0.24 & 2.14 \\
\hline Alumina $\left(\mathrm{Al}_{2} \mathrm{O}_{3}\right)$ & 28.2 & 0.58 & 36.3 \\
\hline Calcium Oxide $(\mathrm{CaO})$ & 2.23 & 0.71 & 0.78 \\
\hline Magnesium Oxide & 0.32 & 0.33 & 16 \\
\hline Insoluble residue & - & - & - \\
\hline
\end{tabular}

Table 4: Physical properties of powders

\begin{tabular}{|c|c|c|c|}
\hline \multirow{2}{*}{$\begin{array}{c}\text { Physical } \\
\text { properties }\end{array}$} & \multicolumn{3}{|c|}{ Description } \\
\cline { 2 - 4 } & FA & SF & MK \\
\hline Colour & Grey & Grey & Grey \\
\hline $\begin{array}{c}\text { Specific } \\
\text { Gravity }\end{array}$ & 2.13 & 2.2 & 2.5 \\
\hline
\end{tabular}

\subsection{Mix proportions}

Forty-eight concrete mixes were used in this research. All mixes were designed to have a constant water/cement ratio of 0.45 and made from different types of coarse aggregates namely gravel aggregate, Dolomite aggregate and Basalt aggregate. It is to be noted that a constant content of superplasticizer of $1.5 \%$ by weight of powder was used in the SCC mixes to study the effect of different powders with different dosages and different aggregate type on the properties of SCC. Mix proportions for mixes used in this research are illustrated in Table 5. All mixes shown in the table have a water content of $202.5 \mathrm{~kg} / \mathrm{m}^{3}$, sand content of $875 \mathrm{~kg} / \mathrm{m}^{3}$ and superplasticizer content of $6.75 \mathrm{~kg} / \mathrm{m}^{3}$.
Table 5: Mix proportions

\begin{tabular}{|c|c|c|c|c|c|c|c|}
\hline \multirow{3}{*}{$\begin{array}{l}\text { Mix } \\
\text { code }\end{array}$} & \multicolumn{7}{|c|}{ Content $\mid(\mathrm{kg} / \mathrm{m} 3)$} \\
\hline & \multirow{2}{*}{$\mathrm{OPC}$} & \multicolumn{3}{|c|}{ Coarse aggregate } & \multicolumn{3}{|c|}{ Powder } \\
\hline & & $\mathrm{G}^{*}$ & $\mathrm{~B} * *$ & $\mathrm{D} * * *$ & FA & SF & MK \\
\hline CG & 450 & 875 & $\begin{array}{ll}-- \\
\end{array}$ & --- & --- & --- & --- \\
\hline $\mathrm{CB}$ & 450 & --- & 875 & --- & --- & --- & --- \\
\hline $\mathrm{CD}$ & 450 & --- & --- & 875 & --- & --- & --- \\
\hline GF1 & 427 & 875 & --- & --- & 22.5 & --- & --- \\
\hline GF2 & 405 & 875 & --- & --- & 45 & --- & --- \\
\hline GF3 & 382.5 & 875 & $\begin{array}{ll}-- \\
-\end{array}$ & $\begin{array}{ll}-- \\
-\end{array}$ & 67.5 & --- & --- \\
\hline BF1 & 427 & --- & 875 & --- & 22.5 & --- & --- \\
\hline $\mathrm{BF} 2$ & 405 & --- & 875 & --- & 45 & --- & --- \\
\hline $\mathrm{BF} 3$ & 382.5 & --- & 875 & --- & 67.5 & --- & --- \\
\hline DF1 & 427 & --- & $\begin{array}{ll}-- \\
\end{array}$ & 875 & 22.5 & --- & --- \\
\hline DF2 & 405 & --- & --- & 875 & 45 & --- & --- \\
\hline DF3 & 382.5 & --- & --- & 875 & 67.5 & --- & --- \\
\hline GS1 & 427 & 875 & --- & --- & --- & 22.5 & --- \\
\hline GS2 & 405 & 875 & --- & --- & --- & 45 & --- \\
\hline GS3 & 382.5 & 875 & --- & --- & --- & 67.5 & --- \\
\hline BS1 & 427 & --- & 875 & --- & --- & 22.5 & --- \\
\hline BS2 & 405 & --- & 875 & --- & --- & 45 & --- \\
\hline BS3 & 382.5 & --- & 875 & --- & --- & 67.5 & --- \\
\hline DS1 & 427 & --- & --- & 875 & --- & 22.5 & --- \\
\hline DS2 & 405 & --- & --- & 875 & --- & 45 & --- \\
\hline DS3 & 382.5 & --- & --- & 875 & --- & 67.5 & --- \\
\hline GM1 & 427 & 875 & --- & --- & --- & --- & 22.5 \\
\hline GM2 & 405 & 875 & --- & --- & --- & --- & 45 \\
\hline GM3 & 382.5 & 875 & --- & --- & --- & --- & 67.5 \\
\hline BM1 & 427 & --- & 875 & --- & --- & --- & 22.5 \\
\hline BM2 & 405 & --- & 875 & --- & --- & --- & 45 \\
\hline BM3 & 382.5 & --- & 875 & --- & -- & -- & 67.5 \\
\hline DM1 & 427 & --- & --- & 875 & --- & --- & 22.5 \\
\hline DM2 & 405 & --- & --- & 875 & --- & --- & 45 \\
\hline DM3 & 382.5 & --- & --- & 875 & --- & --- & 67.5 \\
\hline GMF1 & 382.5 & 875 & --- & -- & 22.5 & --- & 45 \\
\hline GMF2 & 360 & 875 & --- & --- & 45 & --- & 45 \\
\hline GMF3 & 337.5 & 875 & --- & --- & 67.5 & --- & 45 \\
\hline BMF1 & 382.5 & --- & 875 & --- & 22.5 & --- & 45 \\
\hline BMF2 & 360 & --- & 875 & --- & 45 & --- & 45 \\
\hline BMF3 & 337.5 & --- & 875 & --- & 67.5 & --- & 45 \\
\hline DMF1 & 382.5 & --- & --- & 875 & 22.5 & --- & 45 \\
\hline DMF2 & 360 & --- & --- & 875 & 45 & --- & 45 \\
\hline DMF3 & 337.5 & --- & --- & 875 & 67.5 & --- & 45 \\
\hline GSF1 & 382.5 & 875 & --- & --- & 22.5 & 45 & --- \\
\hline GSF2 & 360 & 875 & --- & --- & 45 & 45 & --- \\
\hline GSF3 & 337.5 & 875 & --- & --- & 67.5 & 45 & --- \\
\hline BSF1 & 382.5 & --- & 875 & --- & 22.5 & 45 & --- \\
\hline BSF2 & 360 & --- & 875 & --- & 45 & 45 & --- \\
\hline BSF3 & 337.5 & --- & 875 & --- & 67.5 & 45 & --- \\
\hline DSF1 & 382.5 & --- & --- & 875 & 22.5 & 45 & --- \\
\hline DSF2 & 360 & --- & --- & 875 & 45 & 45 & --- \\
\hline DSF3 & 337.5 & --- & --- & 875 & 67.5 & 45 & --- \\
\hline
\end{tabular}




\subsection{Casting and Curing of Test Specimens}

The mixing procedures for all concrete mixes used throughout this study were carried out according to BS 1881: Part 108 (1983). After measuring the fresh properties of the SCC, the concrete was poured into concrete moulds $(150 * 150 * 150 \mathrm{~mm}$ cubes and $100 * 200 \mathrm{~mm}$ cylinders) and left to be compacted under its own weight. The concrete specimens were de-molded after 24 hours and then marked, and stored to the water curing in plastic tank. Tap water was used in curing.

\subsection{Testing of Specimens}

\subsubsection{Fresh concrete}

Before casting SCC, fresh properties should be measured. There are various tests that can be used to investigate the suitability of fresh SCC before placement. Each test can assess single or multiple aspects of the fresh concrete properties and in general the test together can assess the most important aspects of fresh concrete such as flow ability, filling ability, passing ability and the tendency to segregation. The most common test methods that will be used here are slump flow test and V- funnel test.

\subsubsection{Slump Flow Test}

The slump flow is a combination of the wellknown slump test and flow diameter test. To determine the slump flow of fresh concrete, the following test procedures are made. The hollow truncated cone (slump cone $100 \mathrm{~mm}$ top diameter, $200 \mathrm{~mm}$ bottom diameter and $300 \mathrm{~mm}$ height) is placed on the center of a slump flow plate. The cone is filled with fresh SCC. No compaction energy will be applied during the test so that the SCC flows only under the influence of gravity. When the slump cone is lifted, the time between lifting the cone till the concrete reaches the circle of $500 \mathrm{~mm}$ diameter is measured $\left(\mathrm{T}_{50}\right)$. This time must be between 2-5 seconds and the average diameter of the spread concrete is measured and if its value is equal to or more than $60 \mathrm{~cm}$ it will be considered as an acceptable SCC [17-18].

\subsubsection{V-Funnel Test}

Test procedures for the $\mathrm{V}$-funnel test are as follow: The V-funnel is kept firm on the ground and the inside surfaces of the funnel are moistened and the trap door is kept open to allow any surplus water to drain. About 12 liters of concrete is poured into $\mathrm{V}$-funnel to fill it completely without compaction, while keeping the trap door closed. After 10 seconds of filling, the trap door is opened to allow concrete to flow out under gravity. The stop watch is started when the trap door is opened, and the time taken for complete discharge of concrete from funnel is recorded as "flow time". As recommended, the whole test is to be performed within 5 minutes.

\subsubsection{Hardened concrete}

\subsubsection{Compressive strength Test}

Compressive strength test was carried out on $150 * 150 * 150 \mathrm{~mm}$ cubical specimens in a 2 MN hydraulic compression testing machine. The test was carried out at ages of 3 and 28 days. Compressive strength was calculated by dividing the fracture load by the crosssectional area of the specimen. The reported values for compressive strength represent the average results of three specimens.

\subsubsection{Indirect tensile strength Test}

Test procedures for the indirect tensile strength test are as follows:

Length and the diameter of the specimen were recorded. Two plywood bearing strips were placed between the specimen and both 
upper and lower bearing blocks of the testing machine. The load was then applied continuously at constant rate until failure.

Failure load was then determined and the splitting tensile strength was calculated as follows:

$$
\mathbf{T}=2 \mathbf{P} / \boldsymbol{\pi} \mathbf{L D}
$$

where:

$\mathrm{T}=$ Splitting tensile strength $\left(\mathrm{kg} / \mathrm{cm}^{2}\right)$

$\mathrm{P}=$ Maximum (failure) load $(\mathrm{kg})$

$\mathrm{L}=$ Length of the specimen $(\mathrm{cm})$, and

$\mathrm{D}=$ Diameter of the specimen $(\mathrm{cm})$.

\section{RESULTS AND DISCUSSIONS}

\subsection{Properties of Fresh SCC}

It can be seen from Table 6 that, slump flow diameters vary between $65 \mathrm{~cm}$ and $71 \mathrm{~cm}$ and slump flow times (T50) vary from 2.2 seconds to 5 seconds. It can be noticed that all mixes satisfies the allowable range for slump flow time (2 to 6 seconds) and slump flow diameter $(65$ to $80 \mathrm{~cm})$. It is well known that T50 may be accepted as a measure of plastic viscosity, slump flow diameter indicates the yield stress. The VFunnel flow times vary from 6 seconds to 12 seconds, so all mixes satisfied the allowable range for the flowing time (6 to 12 seconds).

The results presented in Table 6 showed that, the mixes containing dolomite as a coarse aggregate have the highest flow time and the mixes containing gravel as a coarse aggregate have the lowest flow time at all levels of powder replacement.
Table 6: Slump flow and v-funnel results for SCC.

\begin{tabular}{|c|c|c|c|}
\hline \multirow{2}{*}{ Mix code } & \multicolumn{2}{|c|}{ Slump } & \multirow{2}{*}{$\begin{array}{l}\text { V-funnel } \\
\text { time }(\mathrm{sec})\end{array}$} \\
\hline & $\mathrm{T} 50(\mathrm{sec})$ & $\mathrm{D}(\mathrm{cm})$ & \\
\hline CG & 2.5 & 69 & 6.4 \\
\hline $\mathrm{CB}$ & 2.6 & 69 & 11.2 \\
\hline$C D$ & 3.6 & 66 & 10.8 \\
\hline GF1 & 3.5 & 65.5 & 9.5 \\
\hline GF2 & 3.1 & 67.5 & 7.1 \\
\hline GF3 & 2.8 & 68.7 & 6.6 \\
\hline BF1 & 4.4 & 66 & 11.7 \\
\hline BF2 & 4 & 67.4 & 11.6 \\
\hline BF3 & 3.1 & 68.5 & 11.3 \\
\hline DF1 & 4.9 & 66 & 11.9 \\
\hline DF2 & 4.4 & 68.5 & 12 \\
\hline DF3 & 3.6 & 67 & 11.5 \\
\hline GS1 & 3.3 & 67.1 & 11.5 \\
\hline GS2 & 3.8 & 66.1 & 11.5 \\
\hline GS3 & 4 & 65.2 & 11.8 \\
\hline BS1 & 3.6 & 67 & 11.4 \\
\hline BS2 & 4 & 67 & 11.2 \\
\hline BS3 & 5 & 65 & 12 \\
\hline DS1 & 3.7 & 65.1 & 12 \\
\hline DS2 & 4 & 66 & 8 \\
\hline DS3 & 3.6 & 65.4 & 6 \\
\hline GM1 & 3 & 66 & 9 \\
\hline GM2 & 2.9 & 66.4 & 7.6 \\
\hline GM3 & 2.7 & 68 & 6.2 \\
\hline BM1 & 3.1 & 71 & 10 \\
\hline BM2 & 4 & 67 & 11.4 \\
\hline BM3 & 2.8 & 70 & 9.8 \\
\hline DM1 & 3.4 & 69 & 12 \\
\hline DM2 & 4.6 & 65.3 & 11 \\
\hline DM3 & 3.8 & 66 & 10.8 \\
\hline GMF1 & 2.4 & 70 & 6.5 \\
\hline GMF2 & 2.7 & 67 & 6.6 \\
\hline GMF3 & 2.2 & 71 & 6.4 \\
\hline BMF1 & 2.8 & 67 & 11.2 \\
\hline BMF2 & 3 & 66.5 & 11.5 \\
\hline BMF3 & 2.3 & 70.3 & 11.3 \\
\hline DMF1 & 4 & 65.5 & 12 \\
\hline DMF2 & 3.3 & 68 & 8 \\
\hline DMF3 & 3.2 & 68 & 7.9 \\
\hline GSF1 & 2.9 & 69 & 6.6 \\
\hline GSF2 & 2.7 & 70.5 & 7 \\
\hline GSF3 & 2.2 & 70 & 6.2 \\
\hline BSF1 & 3 & 68 & 11.3 \\
\hline BSF2 & 3.1 & 68 & 11.5 \\
\hline BSF3 & 2.9 & 68.6 & 11.2 \\
\hline DSF1 & 4 & 65 & 11.8 \\
\hline DSF2 & 3.9 & 67 & 11 \\
\hline DSF3 & 3.5 & 66 & 9 \\
\hline
\end{tabular}




\subsubsection{Effect of fly ash}

At all levels of FA replacement the mixes containing gravel aggregate have the lowest slump flow time and that containing dolomite aggregate gives the highest slump flow time. It can be also noticed that the incorporation of FA increases the slump flow time than the time of the control mix. The addition of 5\% fly ash gives the highest slump flow time with different aggregate types and the increase in FA ratio decrease the slump flow time compared to 5\% FA.

For all aggregate types the addition of FA increase the V-funnel flow time than that of the control mix at all level of replacement. It can be also noticed that the increase in FA decrease the V-funnel flow time compared to $5 \% \mathrm{FA}$ as it gives the highest flow time. The reduction in flow time for the mixes containing dolomite and basalt aggregate was lower than that of the mixes containing gravel aggregate.

\subsubsection{Effect of silica fume}

The incorporation of SF increases the slump flow time than that of the control mix. 15\% SF gives the highest slump flow time with gravel and basalt aggregate but $10 \% \mathrm{SF}$ gives the highest slump flow time with dolomite aggregate. At 5\% SF the gravel aggregate gives the lowest time and the dolomite aggregate gives the highest one and at $10 \% \mathrm{SF}$ the slump flow time almost the same, but at $15 \% \mathrm{SF}$ the dolomite aggregate gives the lowest time and the basalt aggregate gives the highest one.

The addition of SF gives a V-funnel flow time larger than that of control mix at all levels of replacement and with different aggregate type except the mixes that containing dolomite aggregate with the addition of $10 \%$ and $15 \%$ SF. It can be also noticed that the maximum flow time was obtained at $15 \% \mathrm{SF}$ for both gravel and basalt aggregate, but for dolomite aggregate the maximum time was obtained at $5 \% \mathrm{SF}$.

\subsubsection{Effect of metakaoline}

At all levels of MK replacement, the gravel aggregate have the lowest slump flow time and dolomite aggregate gives the highest slump flow time. It can be also noticed that the incorporation of $\mathrm{MK}$ increase the slump flow time than that of the control mix except at 5\% MK with dolomite aggregate. The addition of 5\% MK gives the highest slump flow time with gravel aggregate, while with basalt and dolomite aggregate 10\% MK gives the highest slump flow time. The addition of MK to the mixes containing gravel aggregate gives a $\mathrm{V}$-funnel flow time smaller than the mixes containing basalt and dolomite aggregate at all levels of replacement, and the increase of MK content decreases the flow time compared to 5\% MK for mixes containing gravel and dolomite aggregate. The addition of $10 \%$ MK gives the maximum flow time for basalt aggregate. The addition of $15 \%$ MK to the mixes containing gravel aggregate reduces the flow time than that of the control mix.

\subsubsection{Effect of fly ash with metakaoline}

The addition of 5\% FA at a constant ratio of $10 \%$ MK reduces the slump flow time than that of control mixes with gravel aggregate, while the time increased with basalt and dolomite aggregate. The addition of $10 \% \mathrm{FA}$ at a constant ratio of $10 \% \mathrm{MK}$ increases the slump flow time than that of the control mix incorporating gravel and basalt aggregate while, the time decreased with dolomite aggregate. The addition of $15 \%$ FA decreases the slump flow time than that of the control mix with different aggregate types. 
EFFECT OF CEMENT ALTERNATIVES ON THE MECHANICAL PROPERTIES OF SELF-COMPACTING CONCRETE USING VARIABLE AGGREGATE TYPES

Shehab, Almetwally, El-maged and Emara

\subsubsection{Effect of fly ash with Silica fume}

At all levels of replacement, the mixes containing gravel aggregate have the lowest slump flow time and the mixes containing dolomite aggregate gives the highest time. At a constant ratio of $10 \% \mathrm{SF}$, the addition of $5 \% \mathrm{FA}$ and $10 \% \mathrm{FA}$ increases the slump flow time for all aggregate types than that of control mix. The addition of $15 \%$ FA decreases the slump flow time than that of the control mix for mixes containing gravel and dolomite aggregate, while the time increased for mixes containing basalt aggregate.

\subsection{Properties of Hardened SCC}

The compressive strength and tensile strength of the used concrete mixes at ages of 3and 28 days are summarized in Table 7 and Figs. 2 to11. Fig. 2 and Fig. 3 show the relation between the ratio of fly ash and the compressive strength after 3 and 28 days. It is interesting to note that, for mixes containing gravel and basalt aggregate, there is a marked reduction in the compressive strength of the concretes with increasing FA content, but mixes containing dolomite aggregate has a compressive strength higher than that of the control mix. The addition of $10 \%$ FA with dolomite aggregate gives the highest compressive strength. Results show also that at all levels of FA replacement, the mixes containing gravel aggregate give the lowest compressive strength and the mixes containing dolomite aggregate give the highest ones.
Table 7 Compressive and tensile strengths for SCC.

\begin{tabular}{|c|c|c|c|}
\hline \multirow{2}{*}{ Mix code } & \multicolumn{2}{|c|}{$\begin{array}{c}\text { Compressive strength } \\
\left(\mathrm{kg} / \mathrm{cm}^{3}\right)\end{array}$} & \multirow{2}{*}{$\begin{array}{c}\begin{array}{c}\text { Tensile } \\
\text { strength }\left(\mathrm{kg} / \mathrm{cm}^{3}\right)\end{array} \\
28 \text { days }\end{array}$} \\
\hline & 3 days & 28 days & \\
\hline$C G$ & 199.47 & 249.8 & 40.9 \\
\hline$C B$ & 244.8 & 344.53 & 46.24 \\
\hline$C D$ & 317.33 & 426.13 & 43.1 \\
\hline GF1 & 197.45 & 362.67 & 42.21 \\
\hline GF2 & 181.33 & 353.6 & 37.34 \\
\hline GF3 & 163.2 & 342.27 & 35.39 \\
\hline BF1 & 235.73 & 494.13 & 40.91 \\
\hline BF2 & 226.67 & 469.2 & 43.83 \\
\hline BF3 & 172.27 & 444.27 & 43.51 \\
\hline DF1 & 362.67 & 534.93 & 51.3 \\
\hline DF2 & 408 & 607.47 & 39.29 \\
\hline DF3 & 362.67 & 634.67 & 35.39 \\
\hline GS1 & 299.2 & 362.57 & 48.05 \\
\hline GS2 & 240.27 & 446.53 & 31.17 \\
\hline GS3 & 226.67 & 462.4 & 48.38 \\
\hline BS1 & 315.27 & 453.33 & 41.56 \\
\hline BS2 & 262.93 & 473.73 & 51.04 \\
\hline BS3 & 272 & 525.87 & 37.01 \\
\hline DS1 & 389.87 & 480.53 & 46.43 \\
\hline DS2 & 362.67 & 571.2 & 42.86 \\
\hline DS3 & 308.27 & 473.73 & 56.17 \\
\hline GM1 & 281.07 & 312.8 & 36.69 \\
\hline GM2 & 217.6 & 385.33 & 33.12 \\
\hline GM3 & 226.67 & 299.2 & 41.88 \\
\hline BM1 & 308.27 & 317.33 & 45.78 \\
\hline BM2 & 262.93 & 391.33 & 45.45 \\
\hline BM3 & 235.73 & 310.2 & 39.94 \\
\hline DM1 & 313.27 & 362.67 & 32.14 \\
\hline $\mathrm{DM} 2$ & 353.6 & 489.6 & 44.81 \\
\hline DM3 & 320.33 & 455.6 & 45.78 \\
\hline GMF1 & 210.5 & 267.47 & 41.88 \\
\hline GMF2 & 226.67 & 358.13 & 37.34 \\
\hline GMF3 & 211 & 312.8 & 34.09 \\
\hline BMF1 & 251.6 & 398.93 & 40.58 \\
\hline BMF2 & 272 & 403.47 & 44.48 \\
\hline BMF3 & 228.93 & 480.53 & 38.64 \\
\hline DMF1 & 344.53 & 498.67 & 48.7 \\
\hline DMF2 & 335.47 & 408 & 53.57 \\
\hline DMF3 & 294.67 & 380.8 & 42.53 \\
\hline GSF1 & 244.8 & 281.07 & 41.56 \\
\hline GSF2 & 248 & 392.13 & 39.99 \\
\hline GSF3 & 145.07 & 375.8 & 40.58 \\
\hline BSF1 & 276.53 & 380.8 & 46.1 \\
\hline BSF2 & 290.13 & 403.47 & 45.32 \\
\hline BSF3 & 226.67 & 380 & 47.73 \\
\hline DSF1 & 335.47 & 480.53 & 43.58 \\
\hline DSF2 & 326.4 & 484.5 & 46.43 \\
\hline DSF3 & 290.13 & 428 & 48.7 \\
\hline
\end{tabular}


Fig.3 shows that, the addition of FA increases the compressive strength after 28 days than that of the control mix at all levels of replacement and with the usage of different aggregate types. It can also be noticed that the mixes containing gravel aggregate give the lowest compressive strength and the mixes containing dolomite aggregate give the highest one. The increase in FA content reduces the compressive strength compared to 5\% FA for mixes containing gravel and basalt aggregate, while the compressive strength increased due to the increase in FA content with dolomite aggregate.

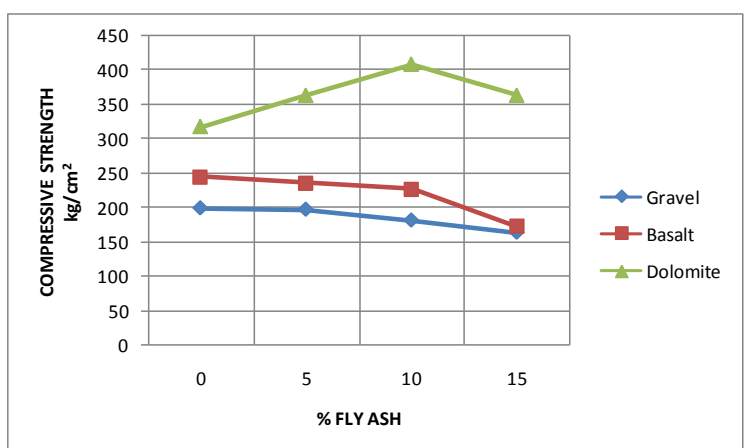

Fig. 2: Compressive strength after 3 days at different $F A$ ratios

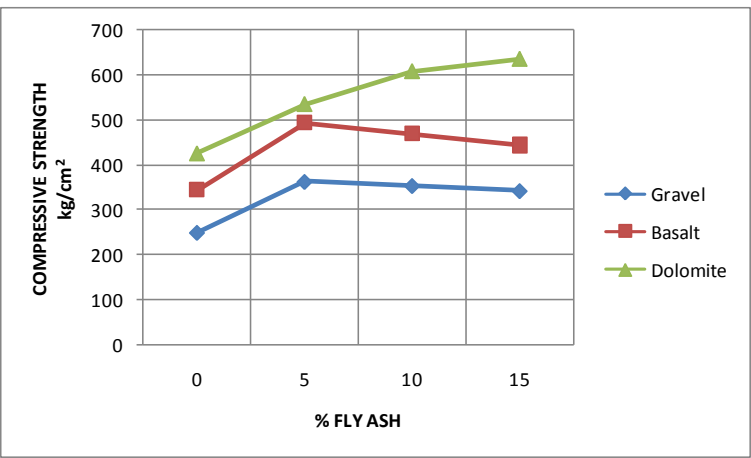

Fig. 3: Compressive strength after 28 days at different $F A$ ratios

Figs. 4 and 5 show the relation between the content of SF and the compressive strength after 3 and 28 days. It shows that, the addition of SF increases the compressive strength than that of the control mix at all level of replacement except the mix having dolomite aggregate with $15 \% \mathrm{SF}$. It also shows that the increase in SF content decreases the compressive strength compared to $5 \% \mathrm{SF}$.

Fig.5 shows that, the addition of SF has a great effect on the values of compressive strength of SCC. As shown the addition of $10 \%$ SF gives the highest values of compressive strength for mixes with dolomite aggregates, while $15 \%$ SF gives the highest value for gravel and basalt aggregate mixes. Generally the addition of SF increases the compressive strength than the control mixes.

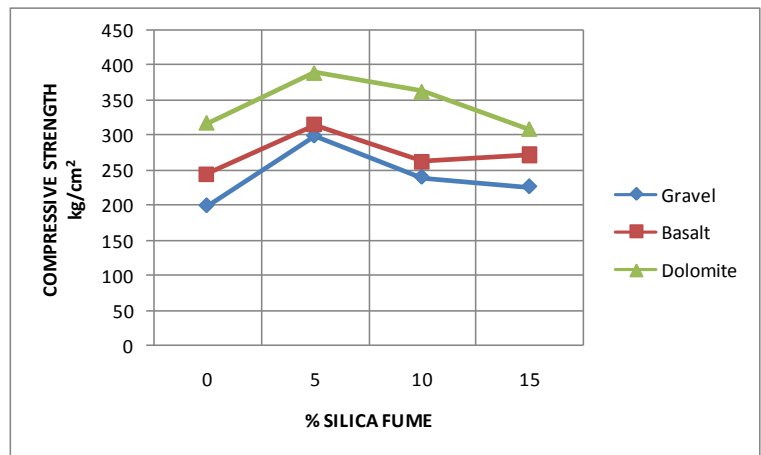

Fig. 4: Compressive strength after 3 days at different $\mathrm{SF}$ ratios

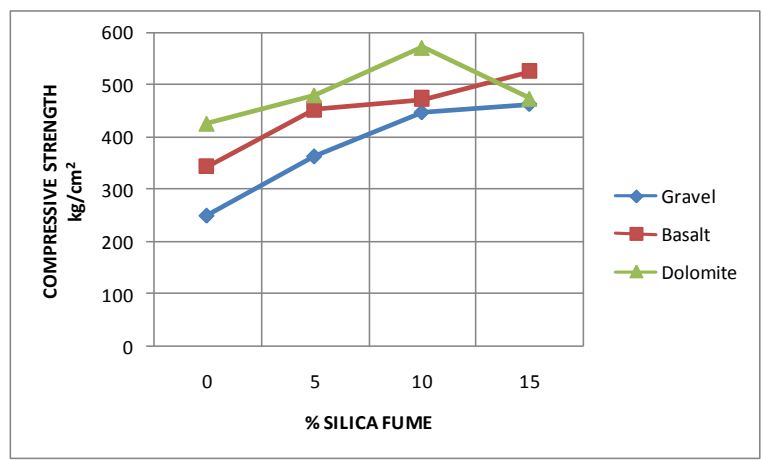

Fig. 5: Compressive strength after 28 days at different $\mathrm{SF}$ ratios

Figs. 6 and 7 show the relation between the content of metakaoline and the compressive strength after 3 and 28 days. They show that, the addition of $\mathrm{MK}$ increases the 3 days compressive strength for all mixes than the control mixes except the mixes containing 5\% MK with dolomite aggregate and $15 \%$ MK with basalt aggregate. The addition of 5\% MK gives the highest compressive strength values for mixes having gravel and 
basalt as a coarse aggregate, while the mixes having dolomite as a coarse aggregate $10 \%$ MK content have the highest values. Fig.7 shows that, the addition of MK to gravel aggregate increases the compressive strength after 28 days at all levels of replacement. It also can be noticed that, for the mixes containing basalt as a coarse aggregate the addition of $10 \% \mathrm{MK}$ increases the compressive strength than the control mix after 28 days. For dolomite aggregate the addition of $10 \%$ and $15 \% \mathrm{MK}$ increase the compressive strength than the control mix after 28 days.

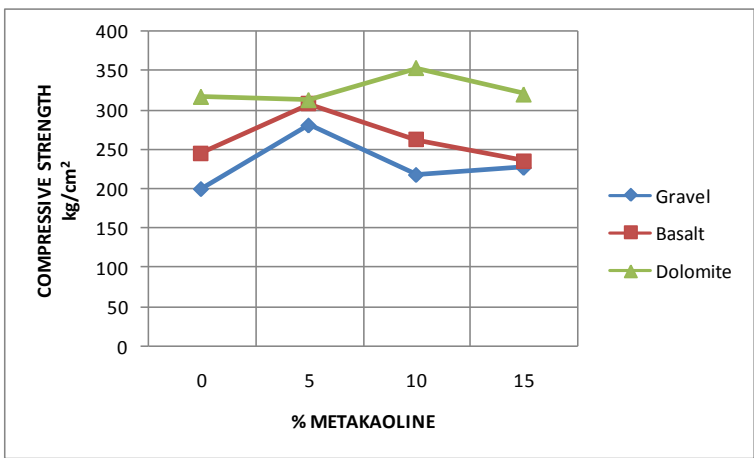

Fig. 6: Compressive strength after 3 days at different MK ratios

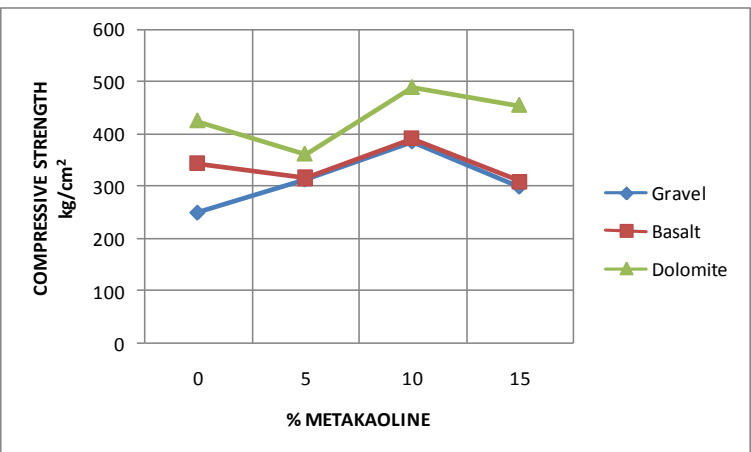

Fig. 7: Compressive strength after 28 days at different MK ratios

Figs. 8 and 9 show the relation between the ratio of $\mathrm{FA}$ at a constant ratio of $10 \% \mathrm{MK}$ and the compressive strength after 3 and 28 days. It shows that, for all aggregate types the addition of $5 \%$ and $10 \% \mathrm{FA}$ at constant content of $10 \%$ MK increases the compressive strength values than the control mix, while the addition of $15 \% \mathrm{FA}$ reduces the compressive strength values. Fig. 9 shows that, for mixes containing gravel and basalt aggregate, the addition of FA increases the compressive strength than the control mix at all levels of replacement, while only 5\% FA content increases the compressive strength for mixes containing dolomite as a coarse aggregate. Fig. 9 shows also that for gravel aggregate, $10 \% \mathrm{FA}$ content give the highest values, while $15 \%$ FA gives the highest values for basalt aggregate.

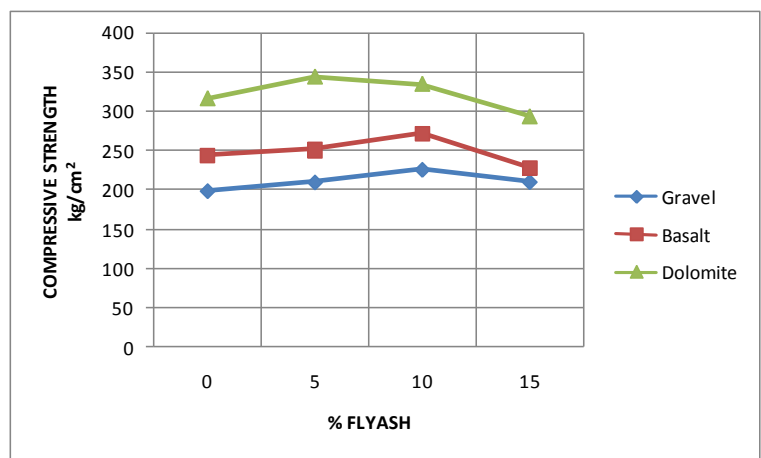

Fig. 8: Compressive strength after 3 days at different $\mathrm{FA}$ ratios and $10 \% \mathrm{MK}$

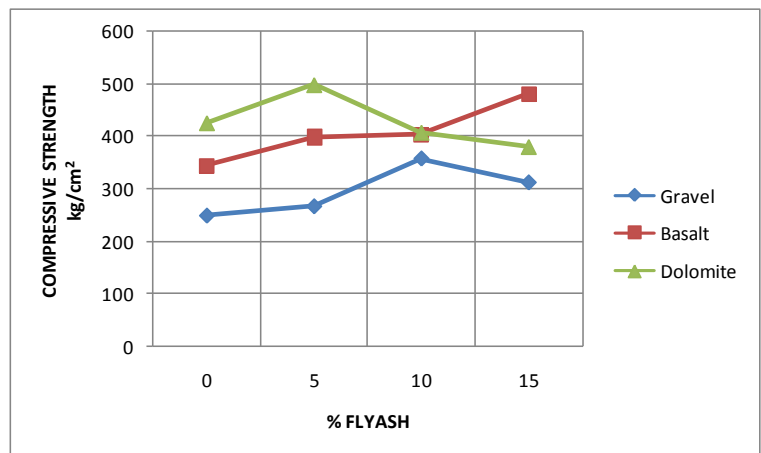

Fig. 9: Compressive strength after 28 days at different $\mathrm{FA}$ ratios and $10 \% \mathrm{MK}$

Figs. 10 and 11 show the relation between the ratio of FA at a constant ratio of $10 \%$ SF and the compressive strength after 3 and 28 days. It shows that, the addition of 5\% and $10 \% \mathrm{FA}$ at a constant percentage $10 \%$ SF to the gravel, basalt and dolomite increase the compressive strength after 3 days. The addition of $15 \% \mathrm{FA}$ at constant content of $10 \%$ SF reduces the strength. It can also be noticed that after 28 days the addition of $5 \%, 10 \%$ and $15 \% \mathrm{FA}$ at a constant content of $10 \% \mathrm{SF}$ increase the compressive strength for gravel, basalt and dolomite aggregates. 


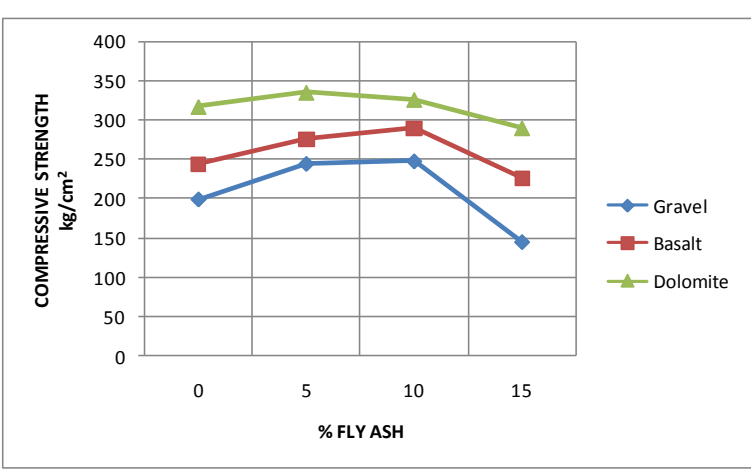

Fig. 10: Compressive strength after 3 days at different $\mathrm{FA}$ ratios and $10 \% \mathrm{SF}$

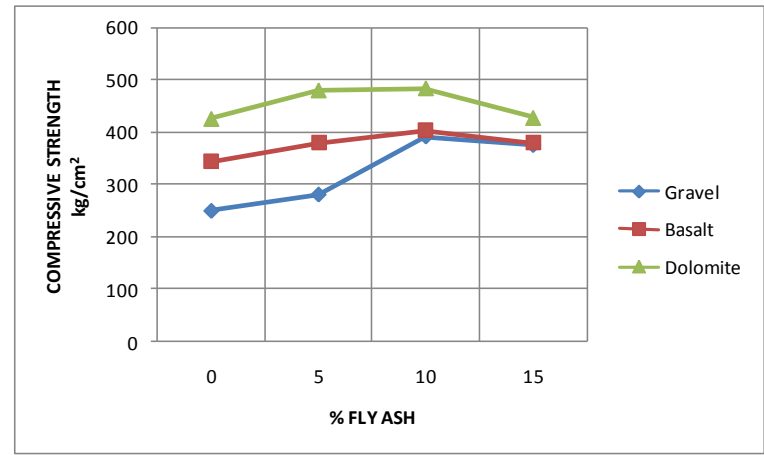

Fig. 11: Compressive strength after 28 days at different $\mathrm{FA}$ ratios and $10 \% \mathrm{SF}$

It is interesting to note that from Table 7, the addition of different powder types with different ratios has no significant impact on the tensile strength of SCC

\section{CONCLUSIONS}

The main conclusions drawn from the results are summarized below:

1- The incorporation of FA, SF, and MK satisfy the self compactability conditions.

2- FA and SF incorporation reduces the compressive strength after 3 days and increases it after 28 days, while the incorporation of $\mathrm{MK}$ increases the strength for both 3 and 28 days.

3- The use of FA with SF and FA with MK induce a good results for the compressive strength after 3 and 28 days
4- The incorporation of FA, SF, and MK has no significant effect on the tensile strength of SCC.

5-Mixes that containing dolomite as coarse aggregate have the highest compressive strength and mixes containing gravel as coarse aggregate have the lowest.

6- The use of gravel, basalt and dolomite as a course aggregate induce acceptable results for both fresh and hardened properties of SCC.

\section{REFERENCES}

[1] Bouzoubaa, N., and Lachemi, M., 2001 "Self-compacting concrete incorporating high volumes of class F fly ash: preliminary results", Cement and Concrete Research, Vol. 31, pp 413420, 2001.

[2] Okamura, H. and Ouchi, M., 1999 "Selfcompacting concrete-development, present and future", Proceedings of the First International RILEM symposium on Self-Compacting Concrete, pp. 3-14.

[3] Zhu W., Gibbs C J., and Bartos P J M., 2001 "Uniformity of in situ properties of self compacting concrete in full-scale structural elements", Cement \& Concrete Composites, Vol. 23, pp. 57-64.

[4] Khayat, K.H., Assaad, J., Daczko J., 2004 "Comparison of Field-oriented Test Methods to Assess Dynamic Stability of Self-Consolidated Concrete", ACI Materials Journal, V. 101, No. 2, March-April, pp. 168-176.

[5] Okamura, H. and Ouchi, M., 2003 "Selfcompacting concrete", Journal of Advanced Concrete Technology, Vol. 1, No. 1, April, pp. 515.

[6] Krieg, W., 2003 "Self-Compacting Concrete: Definition, Development, and Applications", A Technical Paper Presented in the Meeting of the ACI, Saudi Arabia Chapter, Eastern Province, October.

[7]EFNARC,February, 2002 "Specifications and Guidelines for Self-Compacting Concrete", EFNARC, UK (www.efnarc.org), pp. 1-32. 


\section{Shehab, Almetwally, El-maged and Emara}

[8] Ouchi, M., Nakamura, S., Osterson, T., Hallberg, and Lwin, 2003 "Applications of SelfCompacting Concrete in Japan, Europe and the United States," ISHPC, pp.1-20.

[9] Ozyildirim, C. and Lane, D.S., 2003 "Final report on evaluation of self-consolidating concrete", Virginia Transportation Research Council, VTRC 03-R13, June, pp. 1-15.

[10] Khayat, K.H., Assaad, J., 2002 "Air-void Stability in Self-Consolidating Concrete" $A C I$ Materials Journal, V. 99, No. 4, Jul-Aug, pp. 408-416.

[11] Chan, Y.W., Chen, Y.S., Liu, Y.S., 2003 "Development of Bond Strength of Reinforcement Steel in Self- Consolidating Concrete", ACI Materials Journal, V. 100 No. 4, July - August, pp 490-498.

[12] Sonebi, M., (a). 2004 "Applications of statistical models in proportioning mediumstrength self-consolidating concrete", ACI Materials Journal, Vol. 101, No. 5, SeptemberOctober, pp.339-346.

[13] Dehn, F., Holschemacher, K., and Weibe, D., 2000 "Self-Compacting Concrete Time Development of the Material Properties and the Bond Behavior", LACER, No. 5, pp. 115-124.

[14] Mata, L. A., 2004 "Implementation of SelfConsolidating Concrete (SCC) for Prestressed Concrete Girders", MS Thesis, North Carolina State University, November.

[15] Sonebi, M., (b) 2004"Medium strength self-compacting concrete containing fly ash: modeling using factorial experimental plans", Cement and Concrete Research, Vol. 34, pp.1199-1208.

[16] Selcuk Turkel and Yigit altuntas.2009 "The effect of limestone powder, fly ash and silica fume on the properties of self-compacting repair mortars", Cement and Concrete Research, Vol. 34, Part 2, pp.331-343.

[17] Takada, K., Pelova, G. I, and Walraven, J. C.,1998 "Influence of mixing efficiency on the mixture proportion of general purpose selfcompacting concrete", international symposium on High performance concrete and reactive powder concrete, Sherbrook, Canada. pp 16-20.

[18] Ramsburg, P. and Neal, R.E., 2003 "The use of a natural pozzolan to enhance the properties of self-consolidating concrete", (www.oldcastle-precast.com), pp. 1-7. 